\title{
Productive and Reproductive Performance of Different Crossbred Dairy Cattle at Kishoreganj, Bangladesh
}

\author{
Mustasim Famous $^{1 *}$, Asim Chakrabartty Aditya ${ }^{2}$, Shahabuddin Ahmed ${ }^{3}$ and Sabuj Sutradhar ${ }^{2}$
}

${ }^{1}$ Department of Livestock Production and Management, Khulna Agricultural University, Khulna, Bangladesh; ${ }^{2}$ Department of Genetics and Animal Breeding, Sylhet Agricultural University, Sylhet, Bangladesh; ${ }^{3}$ Department of Animal Nutrition, Khulna Agricultural University, Khulna, Bangladesh.

Abstract | The study was conducted at Kishoreganj, Bangladesh to evaluate the productive and reproductive performance of Sahiwal $\times$ Local $(\mathrm{SL} \times \mathrm{L})$, Friesian $\times$ Local $(\mathrm{F} \times \mathrm{L})$, Sindhi $\times$ Local $(\mathrm{S} \times \mathrm{L})$ crossbred during the period of July 2019 to January 2020. A total of 162 crossbred dairy cows under 3 genotypes were studied on the basis of productive and reproductive performances. The average age of puberty of $\mathrm{L} \times \mathrm{F}, \mathrm{L} \times \mathrm{SL}$ and $\mathrm{L} \times \mathrm{S}$ crossbred cattle were 23.7, 26.5 and 29.5 months, respectively. The average age at first fertile service for $\mathrm{L} \times \mathrm{F}$, $\mathrm{L} \times \mathrm{SL}$ and $\mathrm{L} \times \mathrm{S}$ crossbreds' cattle were 24.2, 27.0 and 31.0 months, respectively. The highest gestation length was 285 days and it was for $\mathrm{L} \times \mathrm{S}$ crossbred cattle. The lowest gestation length was 273 days and it was for $\mathrm{L} \times \mathrm{F}$ crossbred cattle. The highest lactation length was observed in case of $\mathrm{L} \times \mathrm{F}$ crossbred (300 days) and lowest was found in case of $\mathrm{L} \times \mathrm{S}$ crossbred (220 days). The highest number of services per conception was 1.66 and it was for $\mathrm{L} \times \mathrm{SL}$ crossbred cattle. The lowest number of services per conception was 1.61 and it was for $\mathrm{L} \times \mathrm{F}$ crossbred cattle. The average post-partum heat period of $\mathrm{L} \times \mathrm{F}, \mathrm{L} \times \mathrm{SL}$ and $\mathrm{L} \times \mathrm{S}$ crossbreds were 114 , 125 and 127days, respectively. The highest Post-Partum Heat Period (PPHP) was 127 days found in case of $\mathrm{L} \times \mathrm{S}$ crossbred cows. The lowest PPHP was found in case of $\mathrm{L} \times \mathrm{F}$ crossbred cows (114 days). The overall productive and reproductive performance of different crossbred were varied. Judging from the overall analysis of the results, it may be concluded that production and reproduction performances of Holstein crossbred are superior to other dairy crossbred in Kishoreganj, Bangladesh.

Editor | Muhammad Abubakar, National Veterinary Laboratories, Park Road, Islamabad, Pakistan.

Received | March 30, 2021; Accepted | April 28, 2021; Published | May 30, 2021

*Correspondence | Mustasim Famous, Department of Livestock Production and Management, Faculty of Veterinary, Animal and Biomedical Sciences, Khulna Agricultural University, Khulna-9100, Bangladesh; Email: mustasimfamous1995@gmail.com

Citation | Famous, M., A.C. Aditya, S. Ahmed and S. Sutradhar. 2021. Productive and reproductive performance of different crossbred dairy cattle at Kishoreganj, Bangladesh. Veterinary Sciences: Research and Reviews, 7(1): 69-76.

DOI | http://dx.doi.org/10.17582/journal.vsrr/2021.7.1.69.76

Keywords | Crossbred, Productive trait, Reproductive trait, Milk yield, Performances

\section{Introduction}

$\mathrm{B}$ angladeshis an agriculture based densely populated country where $51.88 \%$ of people are engaged in agricultural sector (BBS, 2018). Livestock plays a crucial role in the livelihood of a large portion of the population. The magnitude of the contribution of the livestock sub-sector to the GDP is 1.66 percent where it generates 13 percent of the total foreign exchange earnings and provides full-time employment to about 20 percent of the rural population (BOS, 2016). Bangladesh has a high density of cattle population. The total livestock population of Bangladesh is 412.24 million among them cattle are 24.39 million in 2019-20 year. (DLS, 2020). Besides this large population they do not conform to any particular 

Local cattle. Along with Indigenous, some imported improved breeds and their crosses with Indigenous/ Local (not exceeding 10\%) constitutes the national herd. About 92 percent of the dairy cattle is non descriptive indigenous and only 8 percent is reported to be crossbred (BBS, 2006). These Indigenous cattle are of multipurpose in providing milk, draught, meat and dung as fuel and organic fertilizer. The number of milking cows in Bangladesh is 10 million and it represents $47 \%$ of the total cows (Banglapedia 2015). There is a great shortage of milk and meat production in Bangladesh. The yearly milk and meat production in Bangladesh is 7.27 and 6.15 million tons but the national demand is about 14.69 and 7.05 million tons respectively (BBS, 2017). Productive traits directly affect the profitability of the farm. These traits depend largely on the genetic potential of the dam and sire. Profitable breeding could be improved by keeping lactation length, dry period and service period between optimal limits (Alpan, 1994; Cilek and Tekin, 2005). Producing more milk annually is a primary measure of efficiency because maximum production of dairy cows has typically occurred with optimal management conditions (Kellogg et al., 2001). Because of the low milk production of local breeds, exotic breeds are adopted to increase milk production in commercial herds where intensive systems were followed. The revenues of milk production depend on the reproductive efficiency of the herds (Ahmed et al., 2000). Days open and no. of services per conception (NSPC) of the cows have been studied by several investigators due to the economic importance associated with the reproductive efficiency and fertility in dairy cattle. They are important in determining calving interval and influencing milk production (Ali et al., 2003; Riecka and Candrak, 2011). Long calving interval may be the main reproductive disorder of high yielding dairy cattle. Mainly, that is due to either low conception rate (40-50\%) and/or high early embryonic mortality (Rossi et al., 2008). The poor reproductive performance of high yielding cows may affect the overall economic performance of the herd especially under high ambient temperature (Jainudeen and Hafez, 2000). The cattle resources of Bangladesh are mostly of the indigenous type (Bos indicus) with a substantial number of Sindhi, Sahiwal and Holstein-Friesian crossbreds. Indigenous cattle experience late maturity, short lactation length, long calving interval and poor production of milk and draught power but are more disease resistant and apable of thriving in harsh conditions (Majid et al., 1992). Exotic breeds often lack resistance to loca diseases and climatic conditions, produce poorly and lack persistency without considerable high-quality feed and management. In the developing world, indiscriminate use of exotic animal genetic resources and poorly designed breeding schemes are the major reasons for the loss of animal genetic resources. The loss of locally adapted breeds will have long-term negative implications and, in most instances, will reduce food security rather than ensure it. Locally adapted breeds will continue to be valuable in countries because these countries cannot afford the inputs that are required to sustain breeds that have been developed in low stress, high input production systems (A1-Amin et al., 2007).

One way of improving tropical cattle regarding milk production is through cross breding with Bos tauru dairy breeds. This has been widely used in order to combine the high milk yield potential of exotic breeds with the adaptability of the local ones. The first crossbred generation $\left(F_{1}\right)$, usually from native females mated with exotic males, has been a success in most cases. The $\mathrm{F}_{1}$ crosses can produce up to three times more milk and have longer lactation and shorter calving intervals than the local breeds (Kiwuwa et 1., 1983). However back crossing to the European breeds gave rather disappointing results; i.e. milk yield increased only slightly or even declined and fertility deteriorated. This is in addition to the lack of adaptation to tropical conditions (Syrstad, 1989). Crossbred cows are more productive in good nutrition and proper management. Therefore, programs have been taken to improve the genetic potential as well as productivity of non-descript indigenous cows through crossbreeding since 1970 (Bhuiyan, 2006). Rapid improvement in dairy productivity for food security and livelihood leading to poverty reduction is needed in Bangladesh. Therefore, the need for planning to intensify dairy productivity is a crying need of time. In order to maximize overall productivity, the herd must have appropriate combination of genetically high potential breeds along with good feeding and management system. This study was therefore, undertaken to evaluate the consequence of dam genotype on productive and reproductive performance of crossbred milch cows to know the productive and reproductive performance of dairy cattle in Kishoreganj district of Bangladesh.
opeN 0 Access

The study was carried out on the different crossbred cattle in Kishoreganj district from the month of July 2019 to January 2020 . The information dealing with the productive and reproductive performances of crossbred milking cows were collected from farm record sheet and from the owner by direct questionnaires. 17 dairy farms were visited for this purpose. Questionnaire for respective cow's information were prepared in properly designed forms. After preparing the questionnaires, preliminary sorting and checking of data were done and then were prepared for analysis. The questionnaire, made on crossbred dairy cows, contains a detail description of the cows that include 4 productive (Milk yield per day, Peak milk yield per day, Lactation length, Dry period) and 9 reproductive parameters named Birth weight, Age at puberty, Age at first fertile service, Age at first calving, Gestation length, Post-Partum Heat Period (PPHP), Number of services per conception, Days Open (DO), Calving Interval (CI) were measured.

\section{Results and Discussion}

In total, 162 crossbred dairy cows of 3 different genotypes were studied on the basis of productive and reproductive performance.

\section{Productive trait}

Milk yield per day: The average milk yield per day for $\mathrm{L} \times \mathrm{F}, \mathrm{L} \times \mathrm{SL}$ and $\mathrm{L} \times \mathrm{S}$ crossbred cattle were 13.9, 6.3 and 5.3 liter, respectively (shown in Table 1). The highest milk yield per day was recorded 13.9 liter found in case of $\mathrm{L} \times \mathrm{F}$ crossbred cattle. The lowest milk yield per day was 5.3 liter, found in case of $\mathrm{L} \times \mathrm{S}$ crossbred cows. Miazi et al. (2007) found that the average milk yield of Sahiwal $\times$ Local, Friesian $\times$ Local were $4.9 \pm 0.95$ and $6.0 \pm 1.06 \mathrm{~L} /$ day, respectively. Islam et al. (1999) also observed that the average milk yield of the Sahiwal $\times$ Local, Friesian $\times$ Local cows were $2.1 \pm 0.69,4.7 \pm 1.01$ and $6.2 \pm 3.16$ liter/day, respectively. Their findings are slightly lower to the present study. The significant effect of genetic group on dairy milk yield is also found by Khan and Khatun (1998) and Nahar et al. (1992). Sarder et al. (1997) observed that the average milk yield (L/day) for Holstein Friesian cross, Sahiwal cross, Sindhi cross, Jersey cross an Local cows were $7.2 \pm 2.6$ \pm 2.7 and $4 \pm 1.5$ liter, respectively. These results are not similar with this finding. The result of the presen June 2021 | Volume 7 | Issue 1 | Page 71

tudy has a partial agreement with the work of Hasan (1995) who found that the average milk production of crossbred dairy cows was $11.09 \mathrm{~L} /$ day. Similarly, Kabir et al. (2009) reported that the average daily milk yield of Local $\times$ Friesian graded animals was $12.03 \pm 3.73$ L/day while Nahar et al. (1992) found $7.5 \pm 0.1 \mathrm{~L} / \mathrm{d}$. Although the milk production of crossbred cows of this study has partial agreement with the findings of above author. This result indicates that crossbred dairy cows perform their best under our climatic condition. The daily milk yield variation possibly occurred due to following factors-genetic, biological phenomenon, hormonal influences, feeding system, quality and quantity of feed, irresponsible care taker and severe intensive sun light and overall management.

Peak milk yield per day: The peak milk yield per day for $\mathrm{L} \times \mathrm{F}, \mathrm{L} \times \mathrm{SL}$ and $\mathrm{L} \times \mathrm{S}$ crossbred cattle were 14.4 for $\mathrm{L} \times \mathrm{F}, \mathrm{L} \times \mathrm{SL}$ and $\mathrm{L} \times \mathrm{S}$ crossbred cattle were 14.4,
6.4 and 5.4 liter, respectively. The highest peak milk yield per day was 14.4 liter found in case of $L \times F$. The lowest peak milk yield per day was 5.4 liter found in case of $\mathrm{L} \times \mathrm{S}$ crossbred cows. Environment has great influence on genetic group of dams on peak milk yield per day. Breed management and environmental factors are major causes for the variation of peak milk yield per day.

Lactation length: The Average lactation length of $\mathrm{L} \times \mathrm{F}, \mathrm{L} \times \mathrm{SL}$ and $\mathrm{L} \times \mathrm{S}$ crossbred cows were 277,266 and 246 days, respectively (Table 1 ). The highest lactation length was observed in case of $\mathrm{L} \times \mathrm{F}$ crossbred (277 days) and lowest was found in case of $\mathrm{L} \times \mathrm{S}$ crossbred (246 days). Miazi et al. (2007) found that the average lactation length of Sahiwal $\times$ Local and Friesian $\times$ Local were $270 \pm 15$ and $234.0 \pm 24.0$ days, respectively and these results have difference with the present study. Hasan (1995) found that average lactation lengths of Local $\times$ Sahiwal, Friesian $\times$ Local dairy cows were $256.3 \pm 24.37$ and $263.0 \pm$ 30.68 days, respectively. These results are lower from our study. Disease occurrence, managemental system, feeding, housing and nutritional supplement has great influence upon lactation length.

Dry period: The average dry period of $\mathrm{L} \times \mathrm{F}, \mathrm{L} \times \mathrm{SL}$ and $\mathrm{L} \times \mathrm{S}$ crossbred cattle were 87,96 and 116 days, respectively (Table 1$)$. The highest dry period was found in case of $L \times S$ crossbred cattle (116 days). The lowest dry period was found in case of $\mathrm{L} \times \mathrm{F}$ crossbred cattle (87 days). Nahar et al. (1987) found that the average dry period of Sindhi cross and Sahiwal were 

Table 1: Comparative productive performance of dairy farmer from his herd. Environment proper care different crossbred dairy cattle.

$\begin{array}{llll}\text { Traits } & \begin{array}{l}\mathbf{L} \times \mathbf{F} \\ (\text { Mean } \pm \\ \text { SD) N=112 }\end{array} & \begin{array}{l}\mathbf{L} \times \mathbf{S L} \\ (\mathbf{M e a n} \pm \mathbf{S} \pm \mathbf{2 4}\end{array} & \begin{array}{l}\mathbf{L} \times \mathbf{S} \\ (\mathbf{S D}) \mathbf{N}=\mathbf{2 6}\end{array} \\ \text { Milk yield/day (L) } & 13.9 \pm 0.73 & 6.3 \pm 1.01 & 5.3 \pm 0.31 \\ \text { Peak milk yield/day (L) } & 14.35 \pm 0.52 & 6.4 \pm 0.91 & 5.4 \pm 0.69 \\ \text { Lactation length (D) } & 277 \pm 5 & 266 \pm 5 & 246 \pm 5 \\ \text { Dry period (D) } & 87 \pm 9 & 96 \pm 13 & 116 \pm 14 \\ \text { SD: Standard Deriation. } & & & \end{array}$
SD: Standard Deviation.

\section{Reproductive traits}

Birth weight $(\mathbf{k g})$ : The average birth weight of $\mathrm{L} \times \mathrm{F}$, $\mathrm{L} \times \mathrm{SL}$ and $\mathrm{L} \times \mathrm{S}$ crossbred dairy cows were 23.1, 20 and $19.1 \mathrm{~kg}$, respectively (Table 2). The birth weight of $\mathrm{L} \times \mathrm{F}$ crossbred dam was heavier $(23.1 \mathrm{~kg})$ than those other group. The lower birth weight of calf was $19.1 \mathrm{~kg}$, found in case of $\mathrm{L} \times \mathrm{S}$. The result of the present study has close agreement with the work of Kabir and Islam (2009) who found that the average birth weight of Friesian cross was $24.1 \pm 1.73 \mathrm{~kg}$ and for Sahiwal cross was $23.16 \pm 2.13 \mathrm{~kg}$. According to Hasan (1995) the average birth weight of SL $\times$ Pabna was $21.26 \pm 2.89 \mathrm{~kg}$. This result is almost similar to this present study. Similarly, Khan (1990) reported that the average birth weight of calves for Sindhi cross was $17.8 \pm 0.18 \mathrm{~kg}$, which is slightly lower than the present study.

Age at puberty: The average age of puberty of $\mathrm{L} \times$ F, $\mathrm{L} \times \mathrm{SL}$ and $\mathrm{L} \times \mathrm{S}$ crossbred cattle were $23.7,26.5$ and 29.5 months, respectively (Table 2). The higher age was 29.5 month found in case of $\mathrm{L} \times \mathrm{S}$ crossbred. The lower age was 23.7 months found in case of $\mathrm{L}$ $\times$ F crossbred cattle. Kabir et al. (2009) found the differences between crossbred and indigenous cows were significant $(\mathrm{P}<0.01)$. The age at puberty of Local, Shahiwal $\times$ Local and Holstein $\times$ Local are $25.92 \pm$ $1.08,18.0 \pm 00$ and $21.6 \pm 2.40$ months, respectively and these results are slightly lower than our study. Rahman et al. (1998) found that the age of puberty of Friesian $\times$ Local cows were $19 \pm 2.3$ months. Majic et al. (1995) reported that the age at puberty of $\mathrm{L} \times \mathrm{F}$ cattle ranged from 606.4 days $(20.2 \mathrm{~m})$ to 770.31 days $(25.68 \mathrm{~m})$ and these results are slightly lower than our study. In the present study, $\mathrm{L} \times \mathrm{F}$ crossbred reached early age of puberty than other genetic groups of dams. I think this is due to higher nutritional status. also play a vital role in getting puberty earlier. Finally, genetic makeup is the main factor influencing the trait.

Table 2: Comparative reproductive performance of different crossbred dairy cattle.

Reproductive traits $\quad \mathrm{L} \times \mathbf{F} \quad \mathrm{L} \times \mathrm{SL} \quad \mathrm{L} \times \mathbf{S}$ (Mean $\begin{array}{ll}(\mathrm{Mean} \pm & (\mathrm{Mean} \pm \\ \mathrm{SD}) \mathrm{N}=112 & \mathrm{SD}) \mathrm{N}=24\end{array}$ Birth weight $(\mathrm{Kg}) \quad 23.1 \pm 1.21 \quad 20 \pm 1.3 \quad 19.1 \pm 1.11$ $\begin{array}{llll}\text { Age at puberty }(\mathrm{M}) & 23.7 \pm .9 & 26.5 \pm 95 & 29.5 \pm 1.0\end{array}$ Age at first fertile $\quad 24.2 \pm 1.1 \quad 27.0 \pm 1 \quad 31 \pm 1$ service $(\mathrm{M})$

Age at first calving (M) $33.3 \pm 1.20 \quad 36.3 \pm 1 \quad 40.3 \pm 1$ Gestation length (D) $\quad 273 \pm 5 \quad 279 \pm 5 \quad 279 \pm 5$ Postpartum heat period $114 \pm 5 \quad 125 \pm 5 \quad 127 \pm 5$ (D)

$\begin{array}{llll}\text { Days open (D) } & 135 \pm 5 & 146 \pm 5 & 145 \pm 5\end{array}$

$\begin{array}{llll}\text { Service /conception } & 1.61 \pm 0.5 & 1.64 \pm 0.3 & 1.63 \pm 0.5\end{array}$

Calving interval (D) $\quad 410 \pm 10 \quad 426 \pm 10 \quad 426 \pm 10$

SD: Standard Deviation

Age at first fertile service: The average age at first fertile service for $\mathrm{L} \times \mathrm{F}, \mathrm{L} \times \mathrm{SL}$ and $\mathrm{L} \times \mathrm{S}$ crossbreds' cattle were $24.2,27.0$ and 31.0 months, respectively (Table 2). The highest age at first fertile service was 31.0 months found in case of $\mathrm{L} \times \mathrm{S}$. The lowest age of first fertile service is $24.2 \mathrm{~m}$

Majid et al. (1995) observed that the age of first fertile service of $50 \% \mathrm{~L} \times 50 \% \mathrm{~F}$ and $50 \% \mathrm{SL} \times 50 \% \mathrm{~L}$ are $26.3 \pm 2.5$ and $28.6 \pm 3.9$ months, respectively which have close agreement to this present study. Sarde and Hossain (2001) reported that age at first fertile service was $30.3 \pm 7$ months for the indigenous cows which has close agreement with the present study. Rahman et al. (1998) reported that average age of first service for Friesian cross was $47.3 \pm 0.5$ month, which is higher from our study.

Age at first calving: The average age at first calving of $\mathrm{L} \times \mathrm{F}, \mathrm{L} \times \mathrm{SL}, \mathrm{L} \times \mathrm{S}$ crossbred cattle were $33.3,36.3$ and 40.3 months, respectively (Table 2 ). The highest age at first calving was 40.3 months found in case of $\mathrm{L} \times \mathrm{S}$ crossbred cattle. The lowest age at first calving was 33.3 months and it was for $\mathrm{L} \times \mathrm{F}$ crossbred cattle. (2007) showed that the average age at first calving between Friesian $\times$ Local and Sahiwal $\times$ Local were $32.6 \pm 2.32$ and $28.0 \pm 00$ months, respectively and these results are slightly lower from our result. Asaduzzaman and Miah (2004) found that the age at first calving of Friesian $\times$ Local and Sahiwal $\times$ Local were $36.3 \pm 3.08$ and $37.3 \pm 3.01$ months, respectively and the result of the present findings has close agreement with Asaduzzaman and Miah (2004).

Gestation length: The Average gestation length of $\mathrm{L} \times \mathrm{F}, \mathrm{L} \times \mathrm{SL}$ and $\mathrm{L} \times \mathrm{S}$ crossbred cattle were 273 , 279 and 279 days, respectively (shown in Table 2). The highest gestation length is 279 days and it is for $\mathrm{L} \times \mathrm{S}$ crossbred cattle. The lowest gestation length was 273 days and it was for $\mathrm{L} \times \mathrm{F}$ crossbred cattle. Rukonojjaman et al. (2009) found that the average gestation length of Friesian cross, Sahiwal cross and Sindhi cross were $275 \pm 3.95,276 \pm 4.26$ and $275 \pm$ 4.41 month, respectively and the findings are almost similar to our findings. In another study, Hasan (1995) observed that the gestation length for Sindhi cross, Sahiwal cross and Holstein cross were 286, 282 and 284 days, respectively. Here the findings of Mr. Hasan are somewhat higher than our result. Asaduzzaman and Miah (2004) demonstrated the gestation length for Sahiwal $\times$ indigenous and Friesian $\times$ indigenous were 281.1 and 282.7 days, respectively and these findings are somewhat different from the present study. It is observed from the above discussion that crossbreds and indigenous cows have no significant effect on gestation length. Gestation length is a very important factor for dairy farm profitability. The farms, rearing animals which have lower gestation length is sure to obtain the profits.

Post-Partum Heat Period (PPHP): The average Post-partum Heat Period of $\mathrm{L} \times \mathrm{F}, \mathrm{L} \times \mathrm{SL}$ and $\mathrm{L} \times$ S crossbreds were 114, 125 and 127 days, respectively (Table 2). The highest PPHP was 127 days found in case of $\mathrm{L} \times \mathrm{S}$ crossbred cows. The lowest PPHP was found in case of $\mathrm{L} \times \mathrm{F}$ crossbred cows (114 days). Ali (1998) conducted an experiment and reported the PPHP of Crossbred and Local cows were 109.59 and 103.83 days, respectively. The result of the present experiment partially agrees with the findings of Ali (1998). Miazi et al. (2007) found that the average post-partum heat period of Sahiwal $\times$ Local and Friesian $\times$ Local cows were $95.0 \pm 25.0,90.0 \pm 13.42$ days respectively and these results are lower from ou result.

Days open: The average days open of $\mathrm{L} \times \mathrm{F}, \mathrm{L} \times \mathrm{SL}$ Four productive and nine reproductive traits were June 2021 | Volume 7 | Issue 1 | Page 73 and $\mathrm{L} \times \mathrm{S}$ crossbred cattle were 135,146 and 145 days, respectively (Table 2). The highest days open was 146 days found in case of $\mathrm{L} \times \mathrm{SL}$ crossbred cattle. The lowest days open was 135 days and it was for $\mathrm{L} \times \mathrm{F}$ crossbred cattle. This may be due to breed, sire, dam, nutrition, semen type, lactation length and frequency, poor heat detection and extension of postpartum waiting period etc. Khan and Majumder (2011) reported that calving to conception interval in Friesian cross, Sahiwal cross and local cows were $148 \pm 8,139 \pm 8$ and $116 \pm 10$ days, respectively. Here our findings are just reverse. This study shows that Friesian crosses has lower days open than the Sahiwal cross. The days open are also relatively lower in present investigation.

Service per conception: Average service per conception of $\mathrm{L} \times \mathrm{F}, \mathrm{L} \times \mathrm{SL}$ and $\mathrm{L} \times \mathrm{S}$ crossbred cattle were 1.61, 1.64 and 1.63 , respectively (Table 2). The highest number of services per conception was 1.63 and it was for $\mathrm{L} \times \mathrm{SL}$ crossbred cattle. The lowest number of services per conception was 1.61 and it was for $\mathrm{L} \times \mathrm{F}$ crossbred cattle. Mondal et al. $1.63 \pm 0.64,1.60 \pm 0.65$ and $1.60 \pm 0.59$ for Sahiwal cross, Sindhi cross and Friesian cross, respectively and these results are slightly higher from our result. The number of services per conception depends upon the stillness of the inseminator, semen quality, sperm motility and physical condition of the sire. Physically strong and disease-free sires have lower service per conception than the others. Artificial insemination has great influence upon the service per conception of crossbred animals. important reproductive parameter that measures the overall reproductive performance of herd. The average calving interval of $\mathrm{L} \times \mathrm{F}, \mathrm{L} \times \mathrm{SL}$ and $\mathrm{L} \times \mathrm{S}$ were 410 , 426 and 426 months, respectively (shown in Table 2). The highest calving interval was found in case of $\mathrm{L} \times \mathrm{SL}$ and $\mathrm{L} \times \mathrm{S}$ crossbred (426 days). On other hand lowest calving interval was found in case of $\mathrm{L}$ $\times \mathrm{F}$ crossbred (410 days). Mondal et al. (2005) found that the calving intervals were $445 \pm 94.9,451 \pm 89.3$ and $414 \pm 51.4$ days for Sahiwal cross, Sindhi cross, Friesian cross. These results are not similar to present study.

Conclusions and Recommendation (2005) found that average service per conceptions is

Calving interval: Calving interval is the most 
studied. The birth weight of $\mathrm{L} \times \mathrm{F}$ crossbred was heavier $(23.1 \mathrm{~kg})$ than those other group and the lower birth weight of was found in case of $\mathrm{L} \times \mathrm{S}(19.1$ $\mathrm{kg})$. The highest milk yield per day was recorded 13.9 liter, found in case of $\mathrm{L} \times \mathrm{F}$ crossbred cattle as well a the highest peak milk yield per day was 14.4 liter. The higher age at puberty was 29.5 month found in case of $\mathrm{L} \times \mathrm{S}$ crossbred and the lower age was 23.5 month found in case of $\mathrm{L} \times \mathrm{F}$ crossbred cattle. The highest age at first fertile service was 31.0 months found in case of $\mathrm{L} \times \mathrm{S}$ and the lowest age of first fertile service was 24.2 months and it was for $\mathrm{L} \times \mathrm{F}$. The highest age at first calving was 40.3 months found in case of $\mathrm{L} \times$ $\mathrm{S}$ crossbred cattle and the lowest age at first calving was 33.3 months and it was for $\mathrm{L} \times \mathrm{F}$ crossbred cattle. The lowest gestation length was 273 days and it wa for $\mathrm{L} \times \mathrm{F}$ crossbred cattle. The highest PPHP was found in case of $\mathrm{L} \times \mathrm{S}$ crossbred cows (127 days) and the lowest PPHP was found in case of $\mathrm{L} \times \mathrm{F}$ crossbred cows (114 days). The highest days open wa 146 days found in case of $\mathrm{L} \times \mathrm{SL}$ crossbred cattle and the lowest days open was 135 days found in case of $\mathrm{L}$ $\times \mathrm{F}$ crossbred cattle. The highest number of service per conception was in $\mathrm{L} \times \mathrm{SL}$ crossbred cattle (1.64) and the lowest number of services per conception was 1.61 was found in $\mathrm{L} \times \mathrm{F}$ crossbred cattle. The highest lactation length was observed in case of $\mathrm{L}$ $\times \mathrm{F}$ crossbred (277 days) and lowest was found in case of $\mathrm{L} \times \mathrm{SL}$ crossbred (246 days). The highest dry period was found in case of $\mathrm{L} \times \mathrm{S}$ crossbred cattle (116 days) and the lowest dry period was found in case of $\mathrm{L} \times \mathrm{F}$ crossbred cattle (87 days). Judging from the overall analysis of the results, it may be concluded that production performance of Holstein crossbred is superior to other dairy crossbreds. More specifically $\mathrm{L} \times \mathrm{F}$ crossbred performs best. $\mathrm{L} \times \mathrm{SL}$ ranked second in performances While other crossbred performance is relatively lower performance.

Acknowledgements

The authors would like to extend their gratitude to the respondent dairy farmers who were friendly at data collection as well as to the faculty staffs of Sylhet Agricultural University, Bangladesh for their cordial cooperation.

Novelty Statement

The study specifically emphasized the performance of different cross breed dairy cattle which were reared June 2021 | Volume 7 | Issue 1 | Page 74 ly at Kishoreoanj district of Bangladesh.

Author's Contribution

All authors participated a significant role for the manuscript.

Conflict of Interest

The authors have declared no conflict of interest.

References

Ahmed, A.M., El-Saied, U.S., El-Asheeri, K.A. El-Wardani, M.A. and Barkawi, A.H., 2000. Effect of heat detection in buffaloes on length of service period and herd profitability. Egypt. J. Anim. Prod., 37: 67-76. https://doi org/10.21608/ejap.2000.110016

Al-Amin, M., Nahar, A., Bhuiyan, A.K.F.H. and Faruque, M.O., 2007. On farm characterization and present status of North Bengal Grey (NBG) cattle in Bangladesh. AGRI., 40: 5564. Anim. Genet. Res. https://doi.org/10.1017/ S1014233900002194

Ali, A.K., Al-Seaf, A.M.; Alshaikh, M.A., Alkiadess, M.S. and Al-Haidary, A., 2003. Effect of non genetic factors on lactation cure of Holstein Friesian cows in Saudi Arabia. J. King Saud Univ., 15: 115-124.

Ali, M.H., 1998. A comparative performance study on the cross-bred and locals dairy cattle under small holder dairy farming. Condition in Gaibandha district, M.S. thesis, Dep. Dairy Sci., BAU, Ourmensingh.

Alpan, O., 1994. Breeding and feeding of cattle. Ph.D. thesis, Selcuk University, the Institute for Health Sciences, Ankara, Konya, Turkey, pp. 5-57.

Asaduzzaman, M. and Miah, G., 2004. A comparative performance of crossbred and indigenous dairy cows under smallholder dairy farming condition. Bang. Open Univ. J. Agric. Rur. Dev., 7: 12-18.

Banglapedia, 2015. The National Encyclopedia of Bangladesh.

BBS, 2001. Survey on livestock and poultry in Bangladesh. A National Survey Report.

BBS, 2002. Statistical Year book of Bangladesh. Bangladesh Bureau of Statistics, Government of Bangladesh, Bangladesh.

BBS, 2006. Planning Division, Ministry of open $\widehat{O}_{\text {AcCESS }}$

Planning. Government of the People's Republic of Bangladesh

BBS, 2017. Statistical Year book of Bangladesh. Bangladesh Bureau of Statistics, Government of Bangladesh, Bangladesh.

BBS, 2018. Report on Agriculture and Rural Statistics. Government of the People's Republic of Bangladesh.

Bhuiyan, A.K.F.H., 2006. Proven bull production for dairy cattle development in Bangladesh. Seminar Paper, BIAM Foundation.

BOS, 2004. Economic advisory section,Departmen of Finance, Ministry of Finance, Bangladesh.

BOS. 2016. Economic Advisory Section, Department of Finance, Ministry of Finance, Bangladesh.

Chowdhury, A.R., 1995. Influence of season, age, parity, service per conception and conception rate in local and crossbred cattle. M.S. thesis, Dep. Dairy Sci., Bangladesh Agric. Univ. Mymensingh.

Cilek, S. and Tekin, M.E., 2005. The environmental factors effecting milk yield and fertility traits of Simmental cattle rose at Kazova State Farm and phenotypic correlations between these traits. Turk. J. Vet. Anim. Sci., 29: 987-993.

DLS, 2000. An overview, Dhaka, Bangladesh.

DLS, 2012. Ministry of Fisheries and Livestock, Government of the People's Republic of Bangladesh.

DLS, 2020. Livestock econoour at a glance, Ministry of Fisheries and Livestock, Government of the People's Republic of Bangladesh.

Dobson, H. and Alam, M.G.S., 1987. Preliminary investigation into endocrine system of sub fertile cattle: Location of common lesion (rate limiting step). J. Ender., 113: 167-171. https:// doi.org/10.1677/joe.0.1130167

El-Awady, H.G., 2012. Effect of milk yield on economic profitability of Holstein Friesian cows under intensive production system in Egypt. Pak. Vet. J., 5(15): 104-108.

FAO, 2004. Selected indicators of food and agriculture development in Asia-Pacific Region, 1993-2003. Food Agric. Org. U.N., Bangkok, Thailand, pp. 119-121.

Hasan, M.M., 1995. Distribution pattern and some economic dairy characters of locals and crossbred cows in Mymensingh Sadar, M.S. thesis, Department of Dairy Science, Bangladesh Agricultural University, Mymensingh.
Veterinary Sciences: Research and Reviews

m, A. Wadud, A., Rabbani, M.G. and Hossain, B., 1999. Rearing practices and milk production of dairy cattle in Thakurgaon district. Bangladesh J. Anim. Sci., 27: 172-176.

Islam, M.N., Rahman, M.M. and Faruque, S., 2002. Reproductive peformance of different crossbred and indigenous dairy cattle under small holder farming condition in Bangladesh. Online J. Biol. Sci., 2(4): 205-207. https://doi. org/10.3923/jbs.2002.205.207

Islam, M.S. and Kundu, S.K., 2011. Impact of genotypes and parity on reproductive and Productive attributes in dairy cattle of natore district, Bangladesh. J. Life Earth Sci., 6: 91-96 https://doi.org/10.3329/jles.v6i0.9727

Islam, S.K.M.A., Hoque, M.A., Alam, M.R., Hassan, M.M. and Rahman, M.A., 2006. A cross-sectional study on production performance of stall-fed dairy cattle at Central Cattle Breeding Station (CCBS), Savar, Dhaka. Bangladesh J. Vet. Med., 4(1): 61-63. https:// doi.org/10.3329/bjvm.v4i1.1527

Jainudeen, M.R. and Hafez, E.S., 2000 Reproduction in farm animals, reproductive failure in females, reproductive failure, 8(4): 294-322.

Kabir, F. and Islam, M.R., 2009. Comperative study on productive and reproductive performance of local and different crossbred dairy cows at daulatpur, Khulna in Bangladesh. Bangladesh Res. Publ. J., 3(2): 909-914.

Kellogg, D.W., Pennington, J.A., Johnson, Z.B. and Panivivat, R., 2001. Survey of management practices used for the highest producing DHI herds in the United States. J. Dairy Sci., 84: 120-127. https://doi.org/10.3168/jds.S00220302(01)70206-8

Kiwuwa, G.H. Trail, J.C.M. Kurtu, M.Y. Worku, G. Anderson, F. and Durkin, J. 1983. Crossbreed dairy cattle productivity in Arsi region, Ethiopia. ILCA Research Report 11 International Livestock Centre for Africa 1-29.

Khan, M.A.A., 1990. A comparative study on the reproductive efficiency of native and crossbred cows, MS Thesis. Dept. of Animal Breeding and Genetics, Bangladesh Agricultural University, Mymensingh, Bangladesh.

Khan, M.k.I. and Mazumder, J., 2011. Economic selection index using different milk production traits of Holstein and its crossbreds. Turk. J. Vet. Anim. Sci., 35(4): 255-261. 
Khan,M.K.I.and Khatun,M.J.,1998.Performances of F1 crossbred cows at Baghabarighat milk shed area. Bangladesh J. Anim. Sci., 27: 183186.

Kober, A.K.M.H., Deabnath, G.K., Chanda, G.C., Chanda, T. and Amin, M.R., 2003. Economic traits of different dairy cows under village condition. Pak. J. Biol. Sci., 6(10): 902-904. https://doi.org/10.3923/pjbs.2003.902.904

Majid, M., Nahar, T.N., Talukder, A.I. and Rahman, M.A., 1995. Reproductive performance of pure breed, $\mathrm{F}_{1}, \mathrm{~F}_{2}$ and $\mathrm{F}_{3}$ cows related at Savar Dairy Farm. Bangladesh J. Livest. Res., 2: 53-62.

Majid, M.A., Nahar, T.N. and Jalil, M.A., 1992. Breeding for cattle improvement in Bangladesh. Proceeding fourth national conference. Bangladesh Anim. Husb. Assoc., pp. 169-181.

MALR., 2000. Economic Affairs Sector, Agricultural Statistics data, Arab Republic of Egypt, 2: 33-58.

Miazi, O.F., Hossain, M.E. and Hassan, M.M., 2007. Productive and reproductive performance of crossbred and indigenous Dairy cows under rural conditions in Comilla. Bangladesh. Univ. J. Zool. Rajshahi Univ., 26: 67-70. https://doi. org/10.3329/ujzru.v26i0.702

Mondal, S.C., Alam, M.M., Rashid, M.M., Ali, M.Y. and Hossain, M.M., 2005. Comparative study on the productive and reproductive performance of different dairy genotypes reared in Bangladesh Agricultural University Dairy Farm. Pak. J. Nutr., 4(4): 222-225. https://doi. org/10.3923/pjn.2005.222.225

Nahar, N., Mostafa, K.G. and Amin, M.R., 1987. Comparative study on the performance of $\mathrm{F}$. cross-bred cows. Bangladesh J. Anim. Sci., 18(1-2): 55-62.

Nahar, T.N., Islam, M. and Hasnath, M.A., 1992. A comparative study on the performance of $F_{1}$ cross breeds cows under rural condition. AsianAust. J. Anim. Sci., 5: 435-438. https://doi. org/10.5713/ajas.1992.435

Rahman, M.F., Islam, M.S., Hossain, M.A., Prodhan, M.A.M. and Rahman, A., 1987.
Return from investment in dairying in a selected area of Bangladesh. A comparative financial analysis of local and crossbred dairy farms. Bangladesh J. Agric. Econ., 20(1): 67-84.

Rahman, M.M., Islam, M.N. and Dev, A., 1998. A productive and reproductive performances of indigenous and crossbred under village management condition. J. Prog. Agric., 1 and 2: 95-99

Riecka, Z. and Candrák, J., 2011. Analysis of relationship between production and reproduction traits of Holstein cattle population in the Slovak Republic. Anim. Sci. Biotechnol., 44: 332-336.

Rokonuzzaman, M., Hassan, M.R., Islam S. and Sultana, S., 2009. Productive and reproductive performance of crossbred and indigenous dairy cows under smallholder farming system. J. Bangladesh Agric. Univ., 7(1): 69-72. https:// doi.org/10.3329/jbau.v7i1.4801

Rossi, F., Righi, F., Romanelli, S. and Quarantelli, A., 2008. Reproductive efficiency of dairy cows under negative energy balance conditions. Ann. Fac. Med. Vet. Di. Parma., 10(12): 173-180.

Sarder, M.J.U., 2006. A comparative study on reproductive performance of cross-bred dairy cows at greater Rajshahi district. J. Anim. Vet. Adv., 5(8): 679-685.

Sarder and Hossain. 2001. and Reference is Sarder, M.J.U. and Hossain, M.A. 2001. Reproductive and productive performance of indigenous cows. The J.Bangl. Vetei. 18 (2):123-129.

Sarder, M.J.U., Shamsuddin, M., Bhuiyan, M.M.U. and Rahman, M.A., 1997. Individual cows determinant of the fertility and productivity in mini dairy farm. Bangladesh Vet. J., 31: 91-98.

SPSS, 2008. This product used Win Wrap Basic Polar Engineering and consulting.

Syrstad, O., 1989. Dairy cattle cross breeding in the tropics. Performance of secondary crossbred populations. Livest. Prod. Sci., 23: 97-106. https://doi.org/10.1016/0301-6226(89)900080 